\title{
batillot
}

\section{É a inelegibilidade condição, sanção ou causa?}

Daniela Maroccolo Arcuri ${ }^{1}$ (Uniceub, Brasil)

daniela@lossio.adv.br

SHS Quadra 06 - Centro Empresarial Brasil 21 - Bloco A - Sala 301

CEP 70.316-102, Brasília - DF

1. Advogada em Brasília. Sócia fundadora do Escritório de Advocacia Luciana Lóssio. Membro do IBRADE - Instituto Brasileiro de Direito Eleitoral. Membro Fundador da ABRADEP - Academia Brasileira de Direito Eleitoral e Político. Membro da Comissão Especial de Direito Eleitoral do Conselho Federal da Ordem dos Advogados do Brasil. Foi assessora no Conselho Nacional de Justiça, 2008/2010. Foi assessora do Procurador-Geral da República, 1998/2008. 


\section{Resumo}

O presente trabalho tem por objeto a análise da natureza jurídica da inelegibilidade, em razão das várias faces que o instituto pode apresentar. A inelegibilidade vista como condição, precisa ser analisada em sua concepção negativa. Como causa, a sua incidência está vinculada à conduta do pretenso candidato. A inelegibilidade não deixa de ser uma restrição ao exercício da capacidade eleitoral passiva, todavia, em razão de impossibilitar o cidadão de obter a elegibilidade, discute-se a sua natureza de sanção. Não se pretende esgotar o assunto acerca da natureza jurídica das inelegibilidades, mas trazer à baila teses passíveis de questionamento.

Palavras-chaveः Inelegibilidade. Condição. Causa. Sanção.

\section{L' ineleggibilità è la condizione, pena o causa?}

\section{Riassunto}

Questo lavoro ha come scopo l'analisi della natura giuridica dell' ineleggibilità, analizzata secondo i vari aspetti dell' istituto. L'ineleggibilità vista come condizione, deve essere analizzata nella sua concezione negativa. Come causa, la sua incidenza è legata alla condotta del candidato. L'ineleggibilità è una restrizione all'esercizio della capacità elettorale passiva, tuttavia, è anche un'impossibilità per il cittadino di ottenere l'ammissibilità elletorale, perciò alcune persone dibattono sulla sua natura di sanzione. Lo scopo non è di esaurire l'argomento relativo alla natura giuridica dell' ineleggibilità, ma di mostrare tesi che possano essere discusse.

Parole chiaveः Ineleggibilità. Condizione. Causa. Sanzione. 


\section{Introdução}

Quando a Lei Complementar $n^{\circ} 135$, de 4 de junho de $2010^{[1]}$, foi publicada há menos de quatro meses das Eleições Gerais de 2010, gerou forte insegurança aos eleitores brasileiros, e principalmente aos pretensos candidatos, que sentiram mitigada, naquele momento, sua capacidade eleitoral passiva.

A instabilidade decorreu das novas hipóteses de inelegibilidade trazidas pela norma e a possibilidade de sua incidência naquele ano das eleições, numa suposta afronta à soberania do artigo 16 da Constituição Federal ${ }^{355}$.

Mesmo depois de ultrapassada a celeuma da impossibilidade de sua aplicabilidade imedia$\mathrm{ta}^{[2]}$, vieram à baila várias discussóes, dentre elas a aplicação, a fatos passados, das novas hipóteses de inelegibilidade e de seus prazos, o que supostamente poderia configurar um problema de aplicação retroativa (e, nesses termos, inconstitucional) da "sanção" atual de inelegibilidade.

A questão foi novamente submetida à análise do Plenário do Supremo Tribunal Federal (no julgamento conjunto das Açóes Declaratórias de Constitucionalidade n ${ }^{\circ}$ 29/DF e $n^{\circ} 30 /$ DF e da Ação Direta de Inconstitucionalidade n $\left.{ }^{\circ} 4578 / D F\right)$ que, por maioria, entendeu não ser cabível a discussão acerca de uma possível operatividade retroativa da nova lei. $\mathrm{O}$ argumento central invocado diz respeito a não ser a inelegibilidade uma sanção, mas sim uma condição de elegibilidade.

Na oportunidade, assentou o Ministro Luiz Fux, Relator das ADCs 29 e 30 e da ADI 4578, tratar-se a inelegibilidade, "tão-somente, de imposição de um novo requisito negativo para que o cidadão possa candidatar-se a cargo eletivo, que não se confunde com agravamento de pena ou com vis in idem" $[3]$.

Na mesma assentada, o eminente Ministro Ricardo Lewandowski "rememorou inexistir retroatividade, porquanto não se cuidaria de sanção, porém de condição de elegibilidade".

Publicado o acórdão, não restou dúvida sobre a natureza jurídica imputada à inelegibilidade. Basta conferir no trecho pinçado da sua ementa, abaixo transcrito:

6. O princípio da proporcionalidade resta prestigiado pela Lei Complementar $n^{\circ}$ 135/10, na medida em que: (i) atende aos fins moralizadores a que se destina; (ii) estabelece requisitos qualificados de inelegibilidade e (iii) impóe sacrifício à liberdade individual de candidatar-se a cargo público eletivo que não supera os benefícios socialmente desejados em termos de moralidade e probidade para o exercício de referido múnus público.

Em que pese a afirmação trazida na ementa, de que a inelegibilidade é requisito, o tema instiga a discussão em razão das diversas facetas que a inelegibilidade ostenta. A depender do enfoque, analisá-la, por exemplo, como requisito de inelegibilidade, acabaria por exigir uma transposição de sua natureza para o campo da condição que, se positiva, deverá ser preenchida.

Mas em se tratando de inelegibilidade, como se daria o preenchimento desta nova condição de elegibilidade - criada por decisão judicial -, se a sua existência obsta o exercício da capacidade eleitoral passiva? Nesta concepção, há que a classifique como condição negativa de elegibilidade.

355. Art. 16. A lei que alterar o processo eleitoral entrará em vigor na data de sua publicação, não se aplicando à eleição que ocorra até um ano da data de sua vigência. 
Assim sendo, em razão da manifesta repercussão do tema na esfera dos direitos e garantias fundamentais dos cidadãos, faz-se imprescindível o estudo de sua natureza jurídica, até porque, a depender da perspectiva em que visualizado o instituto, talvez sua exigência devesse constar nos incisos do $\S 3^{\circ}$ do artigo 14 da Constituição Federal ${ }^{356}$.

\section{Inelegibilidade \\ 2.1. Conceito}

A definição do instituto da inelegibilidade requer seu confronto com o da elegibilidade, eis que apenas se torna inelegível quem era, antes, elegível. É possível afirmar, nesta concepção, que a inelegibilidade é o óbice à elegibilidade.

A inelegibilidade é o impedimento temporário para o exercício da capacidade eleitoral passiva. Enquanto o elegível está apto para receber o voto, ao inelegível incide empecilho para que isto não aconteça.

Walber de Moura Agra, em seu artigo "A Taxionomia das Inelegibilidades" ${ }^{[4]}$, esclarece que (as inelegibilidades)

[...] só podem aparecer quando já forem concretizadas as condiçôes de elegibilidade. Sem que elas tenham sido cumpridas, não há que se falar em inelegibilidade. Estas atuam diretamente naquelas, cerceando o direito subjetivo de disputar eleições. As primeiras são direitos subjetivos da coletividade, considerados como cláusulas pétreas, enquanto as segundas são situações jurídicas.

356. Art. 14. A soberania popular será exercida pelo sufrágio universal da pelo sufrágio universal e pelo voto direto e secreto, com valor igual para todos, e, nos termos da lei, mediante: [...];

$\$ 3^{\circ}$ - São condições de elegibilidade, na forma da lei:

I - a nacionalidade brasileira;

II - o pleno exercício dos direitos políticos;

III - o alistamento eleitoral;

IV - o domicílio eleitoral na circunscrição;

V - a filiação partidária; Regulamento

VI - a idade mínima de:

a) trinta e cinco anos para Presidente e Vice-Presidente da República e Senador;

b) trinta anos para Governador e Vice-Governador de Estado e do Distrito Federal;

c) vinte e um anos para Deputado Federal, Deputado Estadual ou Distrital, Prefeito, Vice-Prefeito e juiz de paz;

d) dezoito anos para Vereador.

$\S 4^{\circ}$ - São inelegíveis os inalistáveis e os analfabetos. [...].

$\$ 6^{\circ}$ - Para concorrerem a outros cargos, o Presidente da República, os Governadores de Estado e do Distrito Federal e os Prefeitos devem renunciar aos respectivos mandatos até seis meses antes do pleito.

$\S 7^{\circ}$ - São inelegíveis, no território de jurisdição do titular, o cônjuge e os parentes consanguíneos ou afins, até o segundo grau ou por adoção, do Presidente da República, de Governador de Estado ou Território, do

Distrito Federal, de Prefeito ou de quem os haja substituído dentro dos seis meses anteriores ao pleito, salvo se já titular de mandato eletivo e candidato à reeleição. [...];

$\S 9^{\circ}$ Lei complementar estabelecerá outros casos de inelegibilidade e os prazos de sua cessação, a fim de proteger a probidade administrativa, a moralidade para exercício de mandato considerada vida pregressa do candidato, e a normalidade e legitimidade das eleições contra a influência do poder econômico ou o abuso do exercício de função, cargo ou emprego na administração direta ou indireta. [...]. 
Para Agra, inelegibilidade é

[...] a impossibilidade de o cidadão ser eleito para cargo público, em razão de não poder ser votado, ceifando-o de exercer seus direitos políticos na forma passiva. Em decorrência, fica vedado até mesmo o registro de sua candidatura; não obstante, sua cidadania ativa, o direito de votar nas eleições, permanece intacto.

Adriano Soares da Cunha ${ }^{[5]}$ a conceitua como sendo um "estado jurídico de ausência ou perda de elegibilidade". Em seu entender, assim com o conceito jurídico de incapacidade civil apenas tem densidade semântica quando confrontado com o conceito de capacidade civil, de idêntica forma a inelegibilidade apenas pode ser profundamente conhecida se vista em confronto com o conceito de elegibilidade.

Para Paulo Henrique Távora Niess ${ }^{[6]}$, a inelegibilidade consiste no obstáculo posto pela Constituição ou por lei complementar ao exercício da cidadania passiva, por certas pessoas, em razão de sua condição ou em face de certas circunstâncias. É a negação do direito de ser representante do povo no Poder.

Já para José Jairo Gomes, inelegibilidade é o

[...] impedimento ao exercício da cidadania passiva, de maneira que o cidadão fica impossibilitado de ser escolhido para ocupar cargo político-eletivo. Em outros termos, trata-se de fator negativo cuja presença obstrui ou subtrai a capacidade eleitoral passiva do nacional, tornando-o inapto para receber votos e, pois, exercer mandato representativo.

O Ministro Moreira Alves, em seu célebre artigo sobre os "Pressupostos de Elegibilidade e Inelegibilidades" ${ }^{[7]}$, ensina que

Não há que confundir, em face do nosso sistema constitucional, pressupostos (ou condições) de elegibilidade e inelegibilidades, embora a ausência de qualquer daqueles ou incidência de qualquer destas impeça alguém de poder candidatar-se a eleições municipais, estaduais ou federais.

Pressupostos de elegibilidade são requisitos que se devem preencher para que se possa concorrer às eleições. Assim, estar no gozo de direitos políticos, ser alistado como eleitor, estar filiado a partido político, ter sido escolhido como candidato do partido a que se acha filiado, haver sido registrado, pela Justiça Eleitoral, como candidato por esse partido. Já as inelegibilidades são impedimentos que, se não afastados por quem preencha os pressupostos de elegibilidade, lhe obstam concorrer a eleiçóes, ou - se supervenientes ao registro ou se de natureza constitucional - servem de fundamento à impugnação de sua diplomação, se eleito. Não podem eleger-se, por exemplo, os que participam de organização cujo programa ou ação contraria o regime democrático; os declarados indignos do oficialato ou com ele incompatíveis; os que tiverem seus bens confiscados por enriquecimento ilícito.

Portanto, para que alguém posse ser eleito precisa preencher pressupostos de elegibilidade (requisito positivo) e não incidir em impedimentos (requisito negativo).

Quem não reunir essas duas espécies de requisitos - o positivo (preenchimento de pressupostos) e o negativo (não incidência em impedimentos) - não pode concorrer a cargo eletivo. 
Neste contexto, e com base em todas as conceituações expostas, resta claro que, para o efetivo exercício da capacidade eleitoral passiva, as condições de elegibilidade precisam estar presentes enquanto as causas de inelegibilidade devem estar ausentes.

Há quem equipare o inelegível ao não elegível, pelo simples fato de ambos os institutos acarretarem a impossibilidade de o cidadão se eleger.

Todavia, após a comoção em torno da edição da $\mathrm{LC}^{\circ}$ 135/2010, que alterou a $\mathrm{LC} \mathrm{n}^{\circ}$ 64/1990, declarar que um candidato está inelegível equivale, na prática, a lhe impor a pecha de desonesto.

Mas e se o candidato teve seu direito de ser votado obstado apenas e tão somente porque sua filiação partidária foi efetivada a destempo? Seria então razoável equipará-lo àquele cujo óbice à candidatura se deu por rejeição de contas em razão de irregularidades insanáveis, configurando-se ato doloso de improbidade administrativa (art. $1^{\circ}$, I, "g", LC 64/90)?

Após as Eleições Gerais de 2010, em razão do caráter pejorativo da inelegibilidade, adquirido com a edição da Lei da Ficha Limpa - LC no 135/2010 -, a utilização do termo inelegível, empregado tanto nas situações de ausência de condições de elegibilidade como nas de presença das causas de inelegibilidade, merece ser esclarecido caso a caso - e o eleitor também está a merecer essa observação. É inelegível, por exemplo, aquele candidato que foi impedido de ser votado por não ter a idade mínima de vinte e um anos para concorrer ao cargo de Deputado Distrital (art. 14, $\S 3^{\circ}, \mathrm{VI}$, "c", CF/88), mas sua situação, ainda que declarada pela Justiça Eleitoral, difere radicalmente daquela outra, decorrente do novel regramento aqui analisado.

\subsection{Fundamento: o conteúdo ético-moral da regra}

O fundamento ético da inelegibilidade tornou-se mais explícito e enfático com a revisão constitucional de 2002, prevista pelo artigo $3^{\circ}$ do Ato das Disposiçóes Constitucionais Transitórias, quando o constituinte acresceu aos objetivos da inelegibilidade, por meio do $\S 9^{\circ}$ do artigo 14 da Constituição Federal de 1988, um conteúdo moral no intuito de salvaguardar a probidade administrativa e a moralidade para o exercício do mandato.

Em sua redação originária, $\mathrm{o} \S 9^{\circ}$ apenas previa o estabelecimento de inelegibilidades com o intuito de proteger "a normalidade e legitimidade das eleiçôes contra a influência do poder econômico ou o abuso do exercício de função, cargo ou emprego na administração direta ou indireta".

Com a revisão, e por vislumbrar a necessidade de se exigir, dos pretensos candidatos, uma conduta pregressa compatível com o exercício do mandato eletivo, o dispositivo ficou assim redigido, verbis:

$\S 9^{\circ}$ Lei complementar estabelecerá outros casos de inelegibilidade e os prazos de sua cessação, a fim de proteger a probidade administrativa, a moralidade para exercício de mandato considerada vida pregressa do candidato, e a normalidade e legitimidade das eleições contra a influência do poder econômico ou o abuso do exercício de função, cargo ou emprego na administração direta ou indireta. (grifei)

Em verdade, buscou o legislador, conforme ponderou a Ministra Cármen Lúcia nos autos da Consulta $\mathrm{n}^{\circ} 1147 / \mathrm{DF}^{[8]}$ que, "no caso da inelegibilidade ou da elegibilidade, o que se busca é a proteção da sociedade, a garantia da liberdade do voto dirigido para aqueles que têm condições de representação dentro dos princípios acolbidos como valores da sociedade formalizados no sistema". 
E no intuito de proteger a sociedade, o legislador pontuou taxativamente diversos casos de inelegibilidade ${ }^{[9]}$ que, no seu entender, são aptos a impedir que detentores de conduta não ilibada exerçam um mandato eletivo.

Da leitura das novas hipóteses percebe-se que a índole dos ilícitos escolhidos pelo legislador, e assim considerados impedidores do exercício da capacidade passiva eleitoral, não abarcam temas apenas de ordem patrimonial, mas também aqueles referentes à dignidade da pessoa humana, à moral, à ética, à integridade do cidadão, ao meio ambiente.

Todo este contexto permite afirmar que a Lei Complementar no 135/2010 optou por retirar da esfera do eleitor a opção de analisar o peso da vida pregressa dos candidatos para fins de elegê-los ou não. A valoração da vida pregressa dos candidatos, se boa ou ruim, passou a ser fixada, primariamente, pelo legislador, a quem compete, nos termos da Lei, ponderar e decidir quais as condutas capazes de identificar o candidato moralmente incompatível para o exercício do mandato eletivo.

Desta maneira, é fora de dúvida que o fundamento ético-moral para o estabelecimento das novas hipóteses de inelegibilidade, nos termos em que determinado pelo $\S 9^{\circ}$ do artigo 14 da Constituição Federal, inspira a promoção, sempre, da probidade administrativa e da moralidade no exercício dos mandatos eletivos, eis que obsta a eleição daquele cidadão que praticou condutas ofensivas ao conjunto de princípios éticos e morais que regem a conduta humana.

\section{Inelegibilidade como condição negativa}

\subsection{Conceito}

O termo condição, a depender do contexto em que inserido, enseja as mais diversas classificações e conceituações. Todavia, a considerar o campo das elegibilidades e inelegibilidades, apenas nos interessa sua classificação como negativa e positiva.

A condição, em sua concepção habitual, é uma exigência imposta para que algo aconteça - condição positiva ou afirmativa - ou deixe de acontecer - condição negativa.

Para Caldas Aulete ${ }^{[10]}$, o termo condição se refere a qualidades requeridas, como as condições de capacidade ou de moralidade.

Nesta mesma seara, Houaiss ${ }^{[1]}$ a define como "natureza ou qualidade de coisa ou pessoa"; "estado de uma pessoa ou coisa"; "situação, estado ou circunstância de coisa(s) ou pessoa(s) em determinado momento"; "antecedente necessário sem o qual algo não ocorre".

Segundo o dicionário de vocabulário jurídico, a condição negativa, ao contrário da condição positiva, é aquela em que se estipula que a validade do ato depende da não realização do acontecimento ou da não chegada do evento ${ }^{[12]}$.

Ao se tratar das inelegibilidades, a conceituação do termo condição não requer maior minudência, eis que ou a condição é positiva e deverá ocorrer para que o candidato seja elegível (condições de elegibilidade), ou deverá ser negativa (inelegibilidades) e não acontecer, para que o candidato também seja elegível. 


\subsection{Fundamento}

Thales Tácito Pontes Luz de Pádua Cerqueira, em sua obra Tratado de Direito Eleitoral ${ }^{[13]}$, ao cuidar das condições de elegibilidade, pondera que "a capacidade eleitoral passiva refere-se ao direito de ser eleito para mandato eletivo, desde que reunidas as condições de elegibilidade e ausentes as causas de inelegibilidade".

Ao abordar o tema, Adriano Soares da Costa ${ }^{[14]}$ afirma que a inelegibilidade é caracterizada pela "condição negativa de elegibilidade. Noutro giro, poderíamos dizer que a inelegibilidade é a situação de inexistência do direito de ser votado."

Prossegue em sua explanação afirmando que

Todo o Direito Eleitoral existe justamente porque o ordenamento jurídico concede a alguns brasileiros alistados o direito subjetivo de pleitear cargos público eletivos. Tal direito subjetivo nasce se satisfeitas certas condições, as quais ensejam o registro de candidatura, que é o título jurídico que habilita o nacional a participar do prélio eleitoral. Quem possui esse direito subjetivo é elegível, podendo praticar atos de campanha política, pedindo votos em seu nome com vistas a ocupar cargos públicos. A impossibilidade jurídica de concorrer às eleiçóes é o que denominamos inelegibilidade, pouco importando se tal impedimento decorre do fato de não se ter obtido o registro de candidatura, ou do fato de tê-lo perdido por seu cancelamento.

Vê-se que na concepção de Adriano Soares o termo inelegibilidade continua a ser utilizado para ambos os casos de restrição.

Já para o Professor José Jairo Gomes ${ }^{[15]}$, a condição deve ser analisada do ponto de vista lógico, e a define como sendo o

[...] requisito necessário para que algo exista validamente, em conformidade com o ordenamento jurídico. Assim, as condições de elegibilidade são exigências ou requisitos positivos que devem, necessariamente, ser preenchidos por quem queira registrar candidatura e receber votos validamente. Em outras palavras, são requisitos essenciais para que se possa ser candidato e, pois, exercer a cidadania passiva.

Não é demais rememorar o ensinamento do Ministro Moreira Alves, ao afirmar que

Pressupostos de elegibilidade são requisitos que se devem preencher para que se possa concorrer a eleições. Assim, estar no gozo de direitos políticos, ser alistado como eleitor, estar filiado a partido político, ter sido escolhido como candidato do Partido a que se acha filiado, haver sido registrado, pela Justiça Eleitoral, como candidato por esse Partido.

Para Walber de Moura Agra ${ }^{[16]}$,

[...] as condições de elegibilidade são pressupostos imprescindíveis à formação de um direito, enquanto as inelegibilidades são situaçôes jurídicas advindas da realidade fática, que se amoldam em tipologias normativas que estabelecem um risco de macular a lisura e isonomia das eleições. 
Observe-se que a condição, no âmbito das inelegibilidades, é reiteradamente empregada em sua face positiva, ou seja, o seu preenchimento se faz imprescindível para que o cidadão se torne elegível.

Basta conferir no texto da própria Constitucional Federal que, em seu artigo $14, \S 3^{\circ}$, estabelece quais as condições são necessárias para o cidadão tornar-se elegível. Logo, aponta como positivas as condições de elegibilidade, necessárias para o exercício da capacidade eleitoral ativa.

Dessa maneira, sabendo-se que "condições" são impostas pela Constituição Federal, a afirmação advinda do Plenário do Supremo Tribunal Federal, na ocasião do julgamento conjunto das ADCs 29 e 30 e da ADI 4578, exige que a inelegibilidade seja compreendida como uma condição negativa, apesar de não estar descrita no rol taxativo do $\S 3^{\circ}$ do artigo 14 do Texto Constitucional.

Afinal, se a inelegibilidade é pressuposto no entender da Corte Constitucional, como pressuposto deveria vir taxativamente prevista no mencionado artigo 14 do Texto Constitucional.

\section{Inelegibilidade como causa 4.1. Conceito}

O conceito de causa nos leva a ideia de nascimento, de surgimento. A causa gera um acontecimento, um fato. Se for verificada a existência da causa, será gerado um resultado, e a ligação entre a causa e o resultado gera uma relação de causalidade, que permite identificar quem ou o que gerou o fato e quem será afetado por ele.

$\mathrm{Na}$ esfera eleitoral, ao se falar do exercício da capacidade eleitoral passiva, sabe-se que, se o candidato estiver submetido a quaisquer dos impedimentos mencionados no artigo $14 \mathrm{da}$ Constituição Federal ou na legislação complementar respectiva, não estará elegível.

Pode-se afirmar, então, que, diferentemente da condição - que é imposta pelo legislador e independe do cidadão -, a causa está diretamente e pessoalmente vinculada ao candidato e tem como marco a sua conduta, e apenas ela. Dessa maneira, se ele não a praticar e preencher todas as condições de elegibilidade, ele poderá ser eleito.

\subsection{Fundamento}

A doutrina e a jurisprudência, quando abordam o tema, são uníssonas em denominar as inelegibilidades como causas e as elegibilidades como condiçóes.

Neste sentido vem sendo o pronunciamento do Tribunal Superior Eleitoral, do Supremo Tribunal Federal e do Superior Tribunal de Justiça, conforme se verifica nas ementas abaixo transcritas:

ELEIÇÕES 2014. [...]. 1. O art. 11, § 10, da Lei $n^{\circ} 9.504 / 97$ preceitua que as condiçóes de elegibilidade e as causas de inelegibilidade são aferidas no momento do pedido de registro de candidatura, ressalvadas as modificaçóes de fato e de direito posteriores que afastem a inelegibilidade.

2. In casu, a liminar concedida pelo juízo de direito da $1^{\text {a }}$ Vara da Fazenda Pública para suspender os efeitos do acórdão do TCE/MA constitui circunstância superveniente 
capaz de afastar a incidência da causa de inelegibilidade insculpida no art. $1^{\circ}$, I, g, da $\mathrm{LC} \mathrm{n}^{\circ} 64 / 90$.

3. Embargos de declaração acolhidos com efeitos modificativos.

(TSE/ED-AgR-RO no 95558, Ac. de 13/08/2015, Rel. Min. Luiz Fux, DJE $09 / 12 / 2015$ )

ELEIÇÕES 2012. [...]. 1. Conforme dispõe o art. $1^{\circ}$, I, g, da LC nº 64/90, a inelegibilidade alcança as eleições que se realizarem nos 8 (oito) anos seguintes, contados a partir da data da decisão irrecorrível que rejeitou as contas públicas de gestão.

2. Segundo preceitua o art. $11, \S 10$, da Lei $n^{\circ} 9.504 / 97$, as condiçóes de elegibilidade e as causas de inelegibilidade devem ser aferidas no momento da formalização do registro de candidatura, ressalvadas as alterações, fáticas ou jurídicas, supervenientes ao registro, advindas até a data da eleição, nos termos da orientação jurisprudencial fixada por esta Corte Superior para o pleito de 2012 (AgR-REspe no 458-86/GO, Rel. design. Min. Marco Aurélio, DJe de 16.12.2013; e AgR-AR no 87692/PE, Rel. Min. João Otávio de Noronha, DJe de 4.8.2014).

3. A alteração jurisprudencial havida na Sessão de 11.12.2014, no sentido de que as alterações, fáticas ou jurídicas, supervenientes ao registro que afastem a inelegibilidade, poderão ser consideradas até a data da diplomação, e não mais a da eleição (ED-RO no 294-62, Rel. Min. Gilmar Mendes), não se aplica às eleições de 2012, em razão do princípio da segurança jurídica, o qual norteia a aplicação da lei no tempo.

4. Agravo regimental desprovido.

(TSE/AgR-AR no 1050, Acórdão de 10/02/2015, Rel. Min. Luciana Christina Guimarães Lóssio, DJE, Tomo 53, Data 18/3/2015, Página 24 )

Ementa: Agravo regimental interposto pelo autor popular com pedido de reconsideração da liminar concedida sob o argumento de que só órgão colegiado poderia rever decisão de colegiado e falta de plausibilidade jurídica frente à existência de voto divergente. 2. Pleito de efeito suspensivo no extraordinário pelo iminente risco de inelegibilidade. 3. Recorrente condenado em ação popular. 4. Edição da Lei Complementar n. $135 / 2010$ reguladora do dispositivo da CF $14, \S 9^{\circ}$ e a nova causa de inelegibilidade: condenação judicial por órgão colegiado de tribunal. 5. Consulta do Tribunal Superior Eleitoral n. 114.709/2010 pela imediata aplicação da novel norma. 6. A ADPF-AgRg n. 79/PE, rel. Min. Cezar Peluso, em 18.6.2007, como parâmetro permissivo. 7. Liminar referendada pela Turma.

(STF/RE n ${ }^{\circ}$ 281012/PI, Rel. Min. Gilmar Mendes, DJe-040, public em 1.3.2011)

Ementa: [...]. O recurso extraordinário trata da aplicação, às eleições de 2010, da Lei Complementar 135/2010, que alterou a Lei Complementar 64/1990 e nela incluiu novas causas de inelegibilidade. Alega-se ofensa ao princípio da anterioridade ou da anualidade eleitoral, disposto no art. 16 da Constituição Federal. $\mathrm{O}$ recurso extraordinário objetiva, ainda, a declaração de inconstitucionalidade da alínea $\mathrm{k}$ do $\S 1^{\circ}$ do art. $1^{\circ}$ da LC 64/1990, incluída pela LC 135/2010, para que seja deferido o registro de candidatura do recorrente. Alega-se ofensa ao princípio da irretroatividade das leis, da segurança jurídica e da presunção de inocência, bem como contrariedade ao art. $14, \S 9^{\circ}$ da Constituição, em razão do alegado desrespeito aos pressupostos que autorizariam a criação de novas hipóteses de inelegibilidade. Verificado o empate no julgamento do 
recurso, a Corte decidiu aplicar, por analogia, o art. 205, parágrafo único, inciso II, do Regimento Interno do Supremo Tribunal Federal, para manter a decisão impugnada, proferida pelo Tribunal Superior Eleitoral. Recurso desprovido. Decisão por maioria. (STF/RE n ${ }^{\circ}$ 631102/PA, Rel. Min. Joaquim Barbosa, DJe-117, public 20.6.2011)

Ementa: [...]. 8. A expressão contida no caput do art. 26-C, de que o tribunal, no caso o STJ, "poderá, em caráter cautelar, suspender a inelegibilidade" deverá compreendida como a possibilidade de esta Corte, mediante concessão de efeito suspensivo ao recurso especial, ou por outro remédio processual semelhante, suspender os efeitos da condenação de improbidade administrativa, que, pela nova lei, também constitui causa de inelegibilidade. Precedentes: TSE, Consulta n.1147-09.2010.6.00.0000, Classe 10, Brasília, Distrito Federal, Relator Ministro Arnaldo Versiani; e Supremo Tribunal Federal, Ag709.634/DF, decisão do monocrática do Ministro Dias Toffoli, DJ de 2agosto de 2010.

(STJ/MC nº 17112/SP, Rel. Min. Benedito Gonçalves, T1, DJe 28.9.2010)

Do mesmo modo que o instituto da condição reflete a ideia positiva de necessidade de presença para que o fato ocorra, a inelegibilidade como causa tem uma conotação de negatividade, a sugerir que, caso ocorra, gere um fato negativo ou impeça um positivo.

É também neste sentido a doutrina de Joel Cândido ${ }^{[17]}$, ao consignar que, para uma pessoa concorrer a qualquer cargo eletivo, ela precisa possuir as condiçóes de elegibilidade e que contra ela não incida as causas de inelegibilidade:

Não basta, para uma pessoa poder concorrer a qualquer cargo eletivo, que possua ela as condições de elegibilidade que foram examinadas. É mister, ainda, que não incida ela em nenhuma causa de inelegibilidade. Estas, ao contrário daquelas que figuram em lei ordinária, só podem ser fixadas na própria Constituição Federal ou em lei complementar, tão-somente. Constituem-se em restrições aos direitos políticos e à cidadania, já que por inelegibilidade entende-se a impossibilidade, temporária ou definitiva, de uma pessoa ser eleita para um ou mais cargos eletivos.

Portanto, a inelegibilidade é uma hipótese restritiva do exercício da capacidade eleitoral passiva, gerada a partir da conduta do candidato - causa -, considerada, pelo ordenamento jurídico, como incompatível com o exercício do mandato e com a probidade administrativa.

\section{Inelegibilidade como sanção \\ 5.1. Conceito}

Para Hans Kelsen, mesmo que as normas determinem faculdades, delas decorrem necessariamente deveres jurídicos, ainda que por derivação. Isto porque, na sua concepção, o substrato essencial da norma repousa sempre em uma sançãa ${ }^{[18]}$.

Dessa maneira, sabendo-se que toda norma legal traz a própria sanção, é possível dizer que não existe norma desprovida de coerção, afinal, toda norma enseja respeito e obediência. 
Miguel Reale ${ }^{[19]}$ pondera que todas as regras, quaisquer se seja sua natureza, se religiosas, morais, jurídicas, éticas e de etiqueta, foram formuladas para serem cumpridas, para serem executadas. Explica que

[...] se a obediência e o cumprimento são da essência da regra, é natural que todas elas se garantam, de uma forma ou de outra, para que não fiquem no papel, como simples expectativas ou promessas. As formas de garantia do cumprimento das regras denominam-se "sanções".

E as define (as sançóes) como sendo "todo e qualquer processo de garantia daquilo que se determina em uma regra".

Para Reale, as sanções apresentam tantas formas de garantia do cumprimento da norma quantas são as espécies dos distintos preceitos. Sobre a sanção garantidora da regra moral, esclarece:

Quais são as sanções específicas da ordem moral? Em primeiro lugar, temos o remorso, o arrependimento, o amargo exame de consciência. $\mathrm{O}$ homem bem formado, que faltou a um ditame ético, encontra em si mesmo uma censura, uma força psíquica que o coloca na situação de réu diante de si próprio. É o exame de consciência uma forma imediata de sanção dos ditames morais. É a sanção do foro íntimo. Existe, porém, também uma sanção extrínseca ou externa que se reflete na sociedade, pelo mérito ou demérito que o indivíduo granjeia, em razão ou em função dos atos praticados. A sanção de natureza social tem força bem maior do que se supõe. Nós não vivemos apenas voltados para nós mesmos, mas também em função do meio, da sociedade em que agimos. O homem é como que Jano bifronte, com uma face voltada para si próprio e outra que se espelha no meio social. O homem não é uma coisa posta entre outras coisas, mas uma força que se integra em um sistema de forças, sem se desprender do todo. A sanção na Moral obedece a essa dimensão individual-social do homem, porquanto opera tanto no plano da consciência quanto no plano da chamada consciência coletiva. Há uma reação por parte da sociedade, quando o homem age de modo contrário à tábua de valores vigentes. É o que se denomina mérito ou demérito social, como formas de sanção das regras morais.

Diante deste contexto, considerando-se o teor das inelegibilidades trazidas pela nova lei complementar, vê-se que o legislador, ao tirar da esfera do juízo do eleitor a liberdade para escolher, como seu representante, aquele que não tenha uma vida pregressa totalmente moral ou proba, o fez por considerar inapta a sanção pessoal (remorso), e eficaz aquela (sanção) social.

Portanto, a depender da natureza da norma descumprida, as sançóes serão morais, religiosas ou jurídicas, desde que sempre predeterminadas, nos termos do artigo $5^{\circ}$, XXXIX, da Constituição Federal, que prescreve não haver pena ${ }^{[20]}$ sem prévia cominação legal.

Uma vez descumprido o preceito legal e desde que prevista na norma uma consequência para tal desmando, será imputada ao autor da conduta uma sanção correspondente ao ato praticado.

Nas palavras de Damásio de Jesus ${ }^{[21]}$, a sanção "apresenta a característica de retribuição, de ameaça de um mal contra o autor de uma infração penal". 


\subsection{Fundamento}

Muitos operadores do direito, depois de editada a LC n $135 / 2010$, criticaram sua aplicação a fatos passados, por entenderem tratar-se de sanção retrooperante, e que por prejudicar o candidato estaria operando em campo constitucionalmente vedado, julgado por fato anterior à edição da norma complementar.

O Ministro Arnaldo Versiani, ao apreciar o tema nos autos da já mencionada Consulta 1147/2009, defendeu a tese de não ser a inelegibilidade pena. Esclareceu que, realmente, na sua concepção, não há como

[...] se imaginar a inelegibilidade como pena ou sanção em si mesma, na medida em que ela se aplica a determinadas categorias, por exemplo, a de juízes ou a de integrantes do Ministério Público, não porque eles devam sofrer essa pena, mas, sim, porque o legislador os incluiu na categoria daqueles que podem exercer certo grau de influência no eleitorado. Daí, inclusive, a necessidade de prévio afastamento definitivo de suas funções. O mesmo se diga a respeito dos parentes de titular de cargo eletivo, que também sofrem a mesma restrição de elegibilidade. Ainda os inalistáveis e os analfabetos padecem de semelhante inelegibilidade, sem que se possa falar de imposição de pena.

A inelegibilidade, assim como a falta de qualquer condição de elegibilidade, nada mais é do que uma restrição temporária à possibilidade de qualquer pessoa se candidatar, ou melhor, de exercer algum mandato. Isso pode ocorrer por e eventual influência no eleitorado, ou por sua condição pessoal, ou pela categoria a que pertença, ou, ainda, por incidir em qualquer outra causa de inelegibilidade."

Pondera que "a presunção de inocência pode até persistir, não só no processo criminal, como também em outras espécies de processos, mas o cidadão ficará inelegivel se houver decisão por órgão colegiado que o condene naqueles casos estabelecidos em lei".

Em sentido convergente a manifestação do Ministro Pedro Acioli ${ }^{[22]}$, cujo esclarecedor trecho abaixo se transcreve:

[...]. a norma ínsita na LC 64/90 não tem caráter de norma penal, e sim, se reveste de norma de caráter de proteção à coletividade. Ela não retroage para punir, mas sim busca colocar ao seu jugo os desmandos e malbaratações de bens e erário público cometidos por administradores. Não tem o caráter de apená-los por tais, já que na esfera competente e própria é que responderão pelos mesmos.; mas sim, resguardar o interesse público de ser novamente submetido ao comando daquele que demonstrou anteriormente não ser o melhor indicação para o exercício do cargo.

Com base nestas explanaçóes, e na definição de Miguel Reale acerca das diversas espécies de sanção, pode-se dizer que, enquanto na esfera penal a sanção se configura como restrição da liberdade, restritiva de direito ou multa, no campo das inelegibilidades tem-se a restrição temporária do exercício da cidadania passiva.

Walber Agra, ao concluir seu já citado artigo sobre a classificação das inelegibilidades, entende, sim, se tratarem de sanção. E fundamenta sua conclusão nos seguintes termos: 
Conceitua-se como uma sanção, no caso das cominadas, porque há uma conduta típica, antijurídica, que provoca como resultado um cerceamento às prerrogativas do cidadão, atestando o desvalor do ordenamento àquela conduta realizada. Qual seria outra taxionomia enquadrável já que ela advém de um ilícito eleitoral? Se ela representa um castigo oriundo de um ato reprovável praticado, há outra classificação? Se o fator teleológico é impedir a repetição dessas condutas, pode-se admitir sua natureza como simples restrição? Todos esses questionamentos levam apenas a uma conclusão: trata-se, embasada de claridade apodítica, de forma insofismável, de uma sanção.

Foi afirmado por Agra que as inelegibilidades advêm de um ilícito eleitoral. Mas e os inelegíveis por carência de condição de elegibilidade? A carência poderia ser considerada um ilícito penal?

Nos termos da própria lei complementar, a inelegibilidade decorrente de ilícito eleitoral é aquela prevista no item 4 da alínea "e" do inciso I do artigo $1^{\circ}$ da LC 64/90, que torna inelegíveis os que forem condenados, em decisão transitada em julgado ou proferida por órgão judicial colegiado, pelos crimes eleitorais, para os quais a lei comine pena privativa de liberdade.

Outro aspecto importante a ser analisado, é que o cumprimento da sanção é personalíssimo, devendo ser imputada ao infrator e por ele cumprida.

Sobre o cumprimento da sanção, vale trazer à baila importante reflexão do Ministro Luiz Fux, suscitada nos autos da ADC 29 aqui já mencionada, ao ponderar sobre a problemática acerca da extensão da inelegibilidade para além da duração dos efeitos da condenação criminal.

A preocupação surge do fato de, ao ser permitido considerar a inelegibilidade desde a condenação não definitiva, esta extensão pode-se tornar excessiva. E exemplifica:

Em alguns casos concretos, nos quais os indivíduos sejam condenados, por exemplo, à pena de trinta anos, a impossibilidade de concorrer a cargos públicos eletivos pode estender-se em tese por mais de quarenta anos, como disse o Ministro Gilmar Mendes, o que certamente poderia equiparar-se, para efeitos práticos, à cassação de direitos políticos, vedado expressamente pelo artigo 15 da Constituição da República.

Neste contexto, conclui o Ministro:

Então, a disciplina legal de antecipar a inelegibilidade para um momento anterior ao trânsito em julgado torna claramente exagerada a sua extensão por oito anos após a condenação. É algo que não ocorre nem mesmo na legislação penal, que expressamente admite a denominada 'detração."

Todavia, mesmo diante de um contexto onde a inelegibilidade possa durar mais tempo que a maior pena prevista no Código Penal Brasileiro, a natureza restritiva, e não sancionatória, da inelegibilidade se impóe. Isto porque, se o condenado nunca se candidatar, a inelegibilidade nunca o alcançará. 


\section{Conclusão}

As inelegibilidades, sejam elas constitucionais ou infraconstitucionais, primam pela manutenção da ética, pela probidade administrativa, e por uma disputa na qual os candidatos tenham conduta retilínea, sempre visando a ter representantes dignos, que trabalhem pelos cidadãos e por uma sociedade mais justa e igualitária.

Foi neste intuito que o legislador, ao editar a lei complementar nos termos do $\S 9^{\circ}$ do artigo 14 da Constituição Federal, entendeu por bem retirar da esfera de juízo do eleitor, a escolha de candidatos a quem tenham sido imputadas quaisquer das condutas causadoras de inelegibilidade, e criar critérios de avaliação da vida pregressa do candidato, a permitir a manutenção da moralidade no cumprimento do mandado.

Ocorre que, da aplicação desses critérios surgiu a discussão acerca da natureza jurídica da inelegibilidade, se condição (negativa), causa ou sanção.

Se entendida como condição, para possibilitar ao candidato a elegibilidade, a inelegibilidade somente poderá ser concebida em seu viés negativo. Além do mais, importante ressalvar que, como condição, deveria estar descrita no rol do $₫ 3^{\circ}$ do artigo $14 \mathrm{da} C F / 88$, que trata das condições de elegibilidade.

Como causa, a inelegibilidade é uma consequência restritiva do exercício da capacidade eleitoral passiva, gerada a partir da conduta do candidato, que foi considerada, pelo ordenamento jurídico, incompatível com o exercício do mandato e com a probidade administrativa.

Existe ainda quem defenda a sua natureza sancionatória, não obstante o fato de a índole meramente restritiva se impor. Isto porque a inelegibilidade apenas alcança aquele condenado que tenta ser candidato. Se o condenado nunca se candidatar, a inelegibilidade nunca o alcançará.

\section{Notas}

[1] LC 135/2010 alterou a Lei Complementar n 64, de 18 de maio de 1990, que estabelece, de acordo com o $\S 9^{\circ}$ do art. 14 da Constituição Federal, casos de inelegibilidade, prazos de cessação e determina outras providências, para incluir hipóteses de inelegibilidade que visam a proteger a probidade administrativa e a moralidade no exercício do mandato.

[2] LEI COMPLEMENTAR 135/2010, DENOMINADA LEI DA FICHA LIMPA. INAPLICABILIDADE ÀS ELEIÇÕES GERAIS 2010. PRINCÍPIO DA ANTERIORIDADE ELEITORAL (ART. 16 DA CONSTITUIÇÃO DA REPÚBLICA). I. O PRINCÍPIO DA ANTERIORIDADE ELEITORAL COMO GARANTIA DO DEVIDO PROCESSO LEGAL ELEITORAL. O pleno exercício de direitos políticos por seus titulares (eleitores, candidatos e partidos) é assegurado pela Constituição por meio de um sistema de normas que conformam o que se poderia denominar de devido processo legal eleitoral. Na medida em que estabelecem as garantias fundamentais para a efetividade dos direitos políticos, essas regras também compõem o rol das normas denominadas cláusulas pétreas e, por isso, estão imunes a qualquer reforma que vise a aboli-las. $\mathrm{O}$ art. 16 da Constituição, ao submeter a alteração legal do processo eleitoral à regra da anualidade, constitui uma garantia 
fundamental para o pleno exercício de direitos políticos. Precedente: ADI 3.685, Rel. Min. Ellen Gracie, julg. em 22.3.2006. A LC 135/2010 interferiu numa fase específica do processo eleitoral, qualificada na jurisprudência como a fase pré-eleitoral, que se inicia com a escolha e a apresentação das candidaturas pelos partidos políticos e vai até o registro das candidaturas na Justiça Eleitoral. Essa fase não pode ser delimitada temporalmente entre os dias 10 e 30 de junho, no qual ocorrem as convenções partidárias, pois o processo político de escolha de candidaturas é muito mais complexo e tem início com a própria filiação partidária do candidato, em outubro do ano anterior. A fase pré-eleitoral de que trata a jurisprudência desta Corte não coincide com as datas de realização das convenções partidárias. Ela começa muito antes, com a própria filiação partidária e a fixação de domicílio eleitoral dos candidatos, assim como o registro dos partidos no Tribunal Superior Eleitoral. A competição eleitoral se inicia exatamente um ano antes da data das eleições e, nesse interregno, o art. 16 da Constituição exige que qualquer modificação nas regras do jogo não terá eficácia imediata para o pleito em curso.

\section{O PRINCÍPIO DA ANTERIORIDADE ELEITORAL COMO GARANTIA CONS-} TITUCIONAL DA IGUALDADE DE CHANCES. Toda limitação legal ao direito de sufrágio passivo, isto é, qualquer restrição legal à elegibilidade do cidadão constitui uma limitação da igualdade de oportunidades na competição eleitoral. Não há como conceber causa de inelegibilidade que não restrinja a liberdade de acesso aos cargos públicos, por parte dos candidatos, assim como a liberdade para escolher e apresentar candidaturas por parte dos partidos políticos. E um dos fundamentos teleológicos do art. 16 da Constituição é impedir alterações no sistema eleitoral que venham a atingir a igualdade de participação no prélio eleitoral.

III. O PRINCÍPIO DA ANTERIORIDADE ELEITORAL COMO GARANTIA CONSTITUCIONAL DAS MINORIAS E O PAPEL DA JURISDIÇÃO CONSTITUCIONAL NA DEMOCRACIA. O princípio da anterioridade eleitoral constitui uma garantia fundamental também destinada a assegurar o próprio exercício do direito de minoria parlamentar em situações nas quais, por razóes de conveniência da maioria, o Poder Legislativo pretenda modificar, a qualquer tempo, as regras e critérios que regerão o processo eleitoral. A aplicação do princípio da anterioridade não depende de considerações sobre a moralidade da legislação. $\mathrm{O}$ art. 16 é uma barreira objetiva contra abusos e desvios da maioria, e dessa forma deve ser aplicado por esta Corte. A proteção das minorias parlamentares exige reflexão acerca do papel da Jurisdição Constitucional nessa tarefa. A Jurisdição Constitucional cumpre a sua função quando aplica rigorosamente, sem subterfúgios calcados em consideraçóes subjetivas de moralidade, o princípio da anterioridade eleitoral previsto no art. 16 da Constituição, pois essa norma constitui uma garantia da minoria, portanto, uma barreira contra a atuação sempre ameaçadora da maioria.

IV. RECURSO EXTRAORDINÁRIO CONHECIDO E PROVIDO. Recurso extraordinário conhecido para: a) reconhecer a repercussão geral da questão constitucional atinente à aplicabilidade da LC 135/2010 às eleições de 2010, em face do princípio da anterioridade eleitoral (art. 16 da Constituição), de modo a permitir aos Tribunais e Turmas Recursais do país a adoção dos procedimentos relacionados ao exercício de retratação ou declaração de inadmissibilidade dos recursos repetitivos, sempre que as decisóes recorridas contrariarem ou se pautarem pela orientação ora firmada. b) dar provimento ao recurso, fixando a não aplica- 
bilidade da Lei Complementar $n^{\circ}$ 135/2010 às eleições gerais de 2010. ( $\mathrm{RE} \mathrm{n}^{\circ}$ 633703/MG, Rel. Min. GILMAR MENDES, DJe-210 DIVULG 17-11-2011 PUBLIC 18-11-2011 EMENT VOL-02628-01 PP-00065)

[3] Trecho do Voto do Ministro Luiz Fux, exarado às fls. 5/6 do acórdão da ADI 4578/ AC, julgada em 16.2.2012, com acórdão publicado no DJe-127, em 29.6.2012.

[4] AGRA, Walber de Moura. A Taxionomia das Inelegibilidades. Revista Estudos Eleitorais - TSE, Brasília, Volume 6, Número 2, maio/agosto, 2011, p. 29/52.

[5] CUNHA, Adriano Soares da.Instituições de Direito Eleitoral. $8^{a}$ ed. Rio de Janeiro: Lumen Juris, 2009, p. 147/154.

[6] NIESS, Pedro Henrique Távora. Direitos Políticos - condições de elegibilidade e inelegibilidade. São Paulo: Ed. Saraiva, 1994, p. 5.

[7] ALVES, José Carlos Moreira. Pressupostos de elegibilidade e inelegibilidades. In: Estudos de direito público em homenagem a Aliomar Baleeiro, Brasília: Ed. Universidade de Brasília, 1976, p. 225/232.

[8] Consulta n $^{\circ}$ 1147-09.2010.6.00.0000/DF, Rel. Min. Arnaldo Versiani, DJe de 24.9.2010.

[9] [...]; c) o Governador e o Vice-Governador de Estado e do Distrito Federal e o Prefeito e o Vice-Prefeito que perderem seus cargos eletivos por infringência a dispositivo da Constituição Estadual, da Lei Orgânica do Distrito Federal ou da Lei Orgânica do Município, para as eleições que se realizarem durante o período remanescente e nos 8 (oito) anos subsequentes ao término do mandato para o qual tenham sido eleitos;

d) os que tenham contra sua pessoa representação julgada procedente pela Justiça Eleitoral, em decisão transitada em julgado ou proferida por órgão colegiado, em processo de apuração de abuso do poder econômico ou político, para a eleição na qual concorrem ou tenham sido diplomados, bem como para as que se realizarem nos 8 (oito) anos seguintes;

e) os que forem condenados, em decisão transitada em julgado ou proferida por órgão judicial colegiado, desde a condenação até o transcurso do prazo de 8 (oito) anos após o cumprimento da pena, pelos crimes:

1. contra a economia popular, a fé pública, a administração pública e o patrimônio público;

2. contra o patrimônio privado, o sistema financeiro, o mercado de capitais e os previstos na lei que regula a falência;

3. contra o meio ambiente e a saúde pública;

4. eleitorais, para os quais a lei comine pena privativa de liberdade;

5. de abuso de autoridade, nos casos em que houver condenação à perda do cargo ou à inabilitação para o exercício de função pública;

6. de lavagem ou ocultação de bens, direitos e valores; 
7. de tráfico de entorpecentes e drogas afins, racismo, tortura, terrorismo e hediondos;

8. de redução à condição análoga à de escravo;

9. contra a vida e a dignidade sexual; e

10. praticados por organização criminosa, quadrilha ou bando;

f) os que forem declarados indignos do oficialato, ou com ele incompatíveis, pelo prazo de 8 (oito) anos;

g) os que tiverem suas contas relativas ao exercício de cargos ou funçóes públicas rejeitadas por irregularidade insanável que configure ato doloso de improbidade administrativa, e por decisão irrecorrível do órgão competente, salvo se esta houver sido suspensa ou anulada pelo Poder Judiciário, para as eleições que se realizarem nos 8 (oito) anos seguintes, contados a partir da data da decisão, aplicando-se o disposto no inciso II do art. 71 da Constituição Federal, a todos os ordenadores de despesa, sem exclusão de mandatários que houverem agido nessa condição;

h) os detentores de cargo na administração pública direta, indireta ou fundacional, que beneficiarem a si ou a terceiros, pelo abuso do poder econômico ou político, que forem condenados em decisão transitada em julgado ou proferida por órgão judicial colegiado, para a eleição na qual concorrem ou tenham sido diplomados, bem como para as que se realizarem nos 8 (oito) anos seguintes;

\section{$[\ldots]$.}

j) os que forem condenados, em decisão transitada em julgado ou proferida por órgão colegiado da Justiça Eleitoral, por corrupção eleitoral, por captação ilícita de sufrágio, por doação, captação ou gastos ilícitos de recursos de campanha ou por conduta vedada aos agentes públicos em campanhas eleitorais que impliquem cassação do registro ou do diploma, pelo prazo de 8 (oito) anos a contar da eleição;

k) o Presidente da República, o Governador de Estado e do Distrito Federal, o Prefeito, os membros do Congresso Nacional, das Assembleias Legislativas, da Câmara Legislativa, das Câmaras Municipais, que renunciarem a seus mandatos desde o oferecimento de representação ou petição capaz de autorizar a abertura de processo por infringência a dispositivo da Constituição Federal, da Constituição Estadual, da Lei Orgânica do Distrito Federal ou da Lei Orgânica do Município, para as eleiçóes que se realizarem durante o período remanescente do mandato para o qual foram eleitos e nos 8 (oito) anos subsequentes ao término da legislatura;

1) os que forem condenados à suspensão dos direitos políticos, em decisão transitada em julgado ou proferida por órgão judicial colegiado, por ato doloso de improbidade administrativa que importe lesão ao patrimônio público e enriquecimento ilícito, desde a condenação ou o trânsito em julgado até o transcurso do prazo de 8 (oito) anos após o cumprimento da pena;

m) os que forem excluídos do exercício da profissão, por decisão sancionatória do órgão profissional competente, em decorrência de infração ético-profissional, pelo prazo de 8 (oito) anos, salvo se o ato houver sido anulado ou suspenso pelo Poder Judiciário; 
n) os que forem condenados, em decisão transitada em julgado ou proferida por órgão judicial colegiado, em razão de terem desfeito ou simulado desfazer vínculo conjugal ou de união estável para evitar caracterização de inelegibilidade, pelo prazo de 8 (oito) anos após a decisão que reconhecer a fraude;

o) os que forem demitidos do serviço público em decorrência de processo administrativo ou judicial, pelo prazo de 8 (oito) anos, contado da decisão, salvo se o ato houver sido suspenso ou anulado pelo Poder Judiciário;

p) a pessoa física e os dirigentes de pessoas jurídicas responsáveis por doaçóes eleitorais tidas por ilegais por decisão transitada em julgado ou proferida por órgão colegiado da Justiça Eleitoral, pelo prazo de 8 (oito) anos após a decisão, observando-se o procedimento previsto no art. 22;

q) os magistrados e os membros do Ministério Público que forem aposentados compulsoriamente por decisão sancionatória, que tenham perdido o cargo por sentença ou que tenham pedido exoneração ou aposentadoria voluntária na pendência de processo administrativo disciplinar, pelo prazo de 8 (oito) anos; [...].

[10] AULETE, Caldas. Dicionário Contemporâneo da Língua Portuguesa. Vol. II. 3 ed. Rio de Janeiro: Delta, 1980, p. 794.

[11] HOUAISS, Antônio. Dicionário Houaiss da Língua Portuguesa. $1^{\text {a }}$ ed. Rio de Janeiro: Objetiva, 2009, p. 515.

[12] SILVA, De Plácido e. Vocabulário Jurídico. Rio de Janeiro: Editora Forense, 2003, p. $334 / 336$.

[13] CERQUEIRA, Thales Tácito Pontes Luz de Pádua. Tratado de direito eleitoral: tomo I: direito material eleitoral parte I/Thales Tácito Pontes Luz de Pádua Cerqueira, Camila Medeiros de Albuquerque Pontes Luz de Pádua Cerqueira; Christiane de O. Parisi Infante, pesquisadora - São Paulo: Premier Máxima, 2008, p. 273/274.

[14] Idem, p. 148.

[15] Idem, p. 134.

[16] Idem, p. 29/52.

[17] CÂNDIDO, Joel J. Direito Eleitoral Brasileiro. 10a . ed. São Paulo: EDIPRO, 2002, p. $119 / 120$.

[18] SMITH, Juan Carlos. El Desarrollo de las Concepciones Jusfilosoficas, 2a ed., Buenos Aires: Abeledo-Perrot, 1998. 
[19] REALE, Miguel. Liçóes preliminares de direito. São Paulo: Saraiva, 2002, p. 72/76.

[20] Conforme explica o Ministro Luiz Vicente Cernicchiaro - in: Dicionário de Direito Penal, São Paulo, Editora José Bushatsky - a pena é uma das formas de sanção, tratando-se, portanto, de uma sanção criminal.

[21] JESUS, Damásio E. de, 1935. Direito Penal / 1 Volume - Parte Geral. 21ª ed. São Paulo: Editora Saraiva, 1998.

[22] Recurso n 9.052/RS, Rel. Min. Pedro Acioli, PSESS em 30.8.1990.

\section{Referências Bibliográficas}

AGRA, Walber de Moura. A Taxionomia das Inelegibilidades. Revista Estudos Eleitorais TSE, Brasília, Volume 6, Número 2, maio/agosto, 2011, p. 29/52.

ALVES, José Carlos Moreira. Pressupostos de elegibilidade e inelegibilidades. In: Estudos de direito público em homenagem a Aliomar Baleeiro, Brasília: Ed. Universidade de Brasília, 1976, p. 225/232.

AULETE, Caldas. Dicionário Contemporâneo da Língua Portuguesa. Vol. II. 3 ed. Rio de Janeiro: Delta, 1980.

BITENCOURT, Cezar Roberto. Tratado de Direito Penal. São Paulo: Saraiva, 2004.

CERQUEIRA, Thales Tácito Pontes Luz de Pádua. Tratado de direito eleitoral: tomo I: direito material eleitoral parte I/Thales Tácito Pontes Luz de Pádua Cerqueira, Camila Medeiros de Albuquerque Pontes Luz de Pádua Cerqueira; Christiane de O. Parisi Infante, pesquisadora - São Paulo: Premier Máxima, 2008, p. 273/274.

COELHO, Marcus Vinicius Furtado. Direito eleitoral e processo eleitoral - Direito penal eleitoral e direito político, $2^{\text {a }}$ ed. rev., atual. e amp. Rio de Janeiro: Renovar, 2010.

CUNHA, Adriano Soares das Instituições de Direito Eleitoral. $8^{a}$ ed. Rio de Janeiro: Lumen Juris, 2009.

FERNANDES, Lília Maria da Cunha. Direito Eleitoral. Brasília: Fortium, 2005.

GOMES J., José Jairo Gomes. Direito Eleitoral. 5 ed. Belo Horizonte: Del Rey, 2010.

GOMES L., Luiz Flávio. Erro de tipo e erro de proibição. São Paulo. Revista dos

HOUAISS, Antônio. Dicionário Houaiss da Língua Portuguesa. $1^{a}$ ed. Rio de Janeiro: Objetiva, 2009. 
JESUS, Damásio E. de, 1935. Direito Penal / 1 Volume - Parte Geral. 21ª ed. São Paulo: Editora Saraiva, 1998.

REALE, Miguel. Lições preliminares de direito. São Paulo: Saraiva, 2002.

SILVA, De Plácido e. Vocabulário Jurídico. Rio de Janeiro: Editora Forense, 2003.

Tribunais.

TOLEDO, Francisco de Assis. Princípios básicos de direito penal. São Paulo:Saraiva. 
Recebido em: 21/02/2016

Aceito em: 25/03/2016

\section{Como citar}

ARCURI, Daniela Maroccolo. É a inelegibilidade condição, sanção ou causa? Ballot. Rio de Janeiro: UERJ. Volume 2 Número 1 Janeiro/Abril 2016. pp. 185-206. Disponível em: [http://www.e-publicacoes.uerj.br/index. php/ballot]

\section{(c) (1) $\$(0)$}

A Revista Ballot está licenciada sob uma licença Creative Commons Atribuição - Não Comercial - Compartilha Igual 3.0 Não Adaptada. 